\title{
Wybór PISM NIEWYDANYCH ANNY LIBERY (KRAKOWIANKI)
}

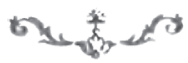

$\AA_{\text {jedną z nielicznych poetek i pisarek, tworzących w Krakowie w drugiej }}^{\text {Nna Libera (1805-1886), używająca pseudonimu Krakowianka, była }}$ połowie XIX wieku, i pierwszą krakowską emancypantką ${ }^{1}$.

Jej życie osobiste nie było łatwe. Jako zaledwie trzyletnie dziecko oddano ją - z powodu ubóstwa w rodzinie - pod opiekę sióstr zakonnych. W Zgromadzeniu Panien Koletek (tercjarek franciszkańskich) przebywała do siódmego roku życia. Wczesne dzieciństwo wspomina w Małym obrazku mojego życia jako pełne surowych zakazów, przeżyte w samotności, pozbawione większej uwagi ze strony rodziców, wyjątkowo przykre i smutne ${ }^{2}$. Ponownie za mury klasztoru (do konwiktu przy szkole dla dziewcząt Panien Prezentek w klasztorze św. Jana w Krakowie) trafiła jako ośmioletnie dziecko. Tam nauczyła się haftu, co w przyszłości miało stać się podstawowym źródłem jej utrzymania. Jako kilkunastoletnia dziewczyna, haftując, zarabiała na życie w jednym z podkrakowskich dworów ${ }^{3}$; umiejętność ta zapewniała jej utrzymanie także w dorosłym życiu. Pobyt w klasztorach i oddawanie dziewcząt do zgromadzeń z powodów finansowych pisarka wielokrotnie krytykowała w swych późniejszych rozprawach. W 1835 roku Libera, jako kobieta nieza-

1 Zob. E. Gracz-Chmura, Literatura romantyczna w Krakowie (1827-1863). Zarys monograficzny, Kraków 2013, s. 259-270. Por. W. Bieńkowski, Anna Libera, „Krakowianka" (1805-1886). Zarys życia i twórczości, Kraków 1968, s. 60.

2 Por. A. Libera, Mały obrazek mojego życia, rkps Biblioteki Czartoryskich, sygn. 11911.

3 Por. A. Libera, Historia mego zawodu literackiego (1852), rkps jw. 
mężna, urodziła córkę Joannę, co stało się powodem jej problemów finansowych i osobistych. Nie mogła bywać już w każdym towarzystwie, prowadziła życie odludne i samotne. Jedynymi jej gośćmi stali się młodzi literaci - tak zwani przedburzowcy ${ }^{4}$, których do starszej nieco od nich poetki zbliżyła podobna tematyka utworów i śmiałe poglądy. Przez pewien czas Libera prowadziła skromny salon poetycki, w którym bywali Michał Bałucki, Adam Bełcikowski, Józef Łepkowski i Józef Szujski. Zwłaszcza z ostatnim z wymienionych pisarzy łączyła Liberę wspólnota myśli, przejawiająca się $\mathrm{w}$ doborze podobnych tematów literackich, realizowanych w formie dramaturgicznej ${ }^{5}$. Dzięki tym znajomościom krakowskiej poetce udało się nawiązać współpracę z czasopismami skierowanymi do kobiet, „Niewiastą” i „Kaliną" 6 .

Twórczość Libery szczególnie trudno zaklasyfikować do któregoś z licznych prądów literackich XIX wieku. Dość konsekwentnie podtrzymywana linia programowa w utworach poetki oscylowała wokół romantycznej ludowości (zaprezentowane w niniejszym wyborze Krakowiaki, 1848), sentymentalnych sielanek (Wiejska rodzina, 1859) i protorealistycznych utworów prozatorskich (Dobra pani i dobra służąca, 1845). Bez wątpienia najistotniejszym elementem dorobku literackiego Libery są właśnie jej poezje - głównie krakowiaki i inne wiersze utrzymane w tematyce związanej z życiem kobiety. Sporą popularnością cieszyły się wydane w Krakowie kolejne tomy wierszy Krakowianki.

Libera funkcjonowała w krakowskim środowisku literackim także jako autorka dramatów. W 1867 roku ukazała się jej Jadwiga, królowa polska ${ }^{8}$. Dotąd niewydane pozostają tragedie pisarki (Jadwiga. Obraz dramatyczny w trzech aktach, Poświęcenie Jadwigi, królowej, Esterka na Łobzowie, Safo. Poetka Grecji) oraz dramaty prezentujące współczesne środowiska miejskie (Ciało i dusza poety), a także komedie (Kłopot o edukację, Kasia i Dorota) ${ }^{9}$.

Por. J. Maciejewski, Przedburzowcy. Z problematyki przełomu między romantyzmem a pozytywizmem, Kraków 1971, s. 214-216.

5 Zarówno Libera, jak i Szujski opracowywali literacko temat królowej Jadwigi, o czym przeczytać można w listach pisarki z lat 1845-1851. Zob. rkps BCz, sygn. 11911.

6 Zob. np.: H. [A. Libera], Apoteoza niewiasty, „Kalina” 1867, nr 27, s. 2.

7 Zob. A.L. Krakowianka [A. Libera], Poezje, Kraków 1842; A.L. Krakowianka [A. Libera], Nowe poezje, Kraków 1846; A.L. Krakowianka [A. Libera], Poezje narodowe, Kraków 1849; A.L. Krakowianka [A. Libera], Wianeczek z wonnych kwiateczków dla dzieci, Kraków 1869.

8 Zob. Anna L... Krakowianka [A. Libera], Jadwiga, Królowa Polski. Dramat w trzech aktach, Kraków 1867.

9 Por. rkps BCz, sygn. 11911. 
Twórczość dramatyczna Libery, zwłaszcza dramaty historyczne (ogłoszony w niniejszym wyborze fragment dramatu o królowej Jadwidze), oscylują już wokół założeń literatury zapowiadającej tendencje pozytywistyczne.

Spod pióra Krakowianki wyszły również utwory prozatorskie - krótkie powieści: Prawda i marzenie. Powieść (1872), Panna Natalia (1862), Mleczne siostry. Powieść obyczajowa (1874). Libera opublikowała także dwa epickie utwory wierszowane; jeden o wyraźnie dydaktycznym przesłaniu - Przygoda z czartem Janka Magury, pijaka, po której poprawił się i został trzeźwym człowiekiem (1845) oraz poświęcony Stanisławowi Orzechowskiemu utwór Apostata. Poemat w VII pieśniach (1879).

Ważną, choć dotąd nieopracowaną i w większości nieopublikowaną, część dorobku pisarskiego Libery stanowią odczyty i rozprawy publicystyczne przede wszystkim o wyraźnie emancypacyjnym przesłaniu, wzywające do polepszenia bytu kobiet. Krakowianka, jako przedstawicielka założonego w 1848 roku Komitetu Polek ${ }^{10}$, podjęła się stworzenia programu mającego usankcjonować kwestie oświatowego, kulturalnego i społecznego funkcjonowania kobiet. Zależało jej przede wszystkim na tym, żeby obudzić w nich potrzebę zmiany, zdawała sobie bowiem sprawę z ich nieufności i braku entuzjazmu wobec jej śmiałych jak na tamte czasy poglądów. Libera dążyła do równouprawnienia obu płci, zarówno w sensie społecznym, jak i politycznym, ale także do zacieśniania więzi opartej na solidarności między kobietami różnych stanów. Pragnęła uświadomić kobietom rolę wykształcenia, które może uniezależnić je od mężczyzn, umocnić ich pozycję społeczną, dać finansową niezależność i w końcu stać się sposobem na wartościowe i spełnione życie ${ }^{11}$.

Większość jej rozpraw, zachowanych jedynie w rękopisach, powstała prawdopodobnie na przełomie lat czterdziestych i pięćdziesiątych XIX wieku. Są to: Kobieta w upodleniu, Kobieta i jej przeznaczenie, Kobieta wobec idei - Idea katolicyzmu, Za chwil niewiele, Koniecznie nam trzeba iść równo $z$ wiekiem, Krakowski mężczyzna, Szanowne rodaczki, Jak wypada się ksztatcić kobiecie, ażeby otrzymała charakter właściwy ${ }^{12}$. Z licznych rozpraw na tematy związane z emancy pacją kobiet, wygłaszanych bądź przygotowywa-

10 Odezwa inaugurująca działalność Komitetu Polek ukazała się nawet w poczytnej „Gazecie Krakowskiej” - zob. A.L. [A. Libera], Komitet Polek, „Gazeta Krakowska” 1848 , nr 244, s. 1.

11 Wśród patronek duchowych Libery były znane emancypantki, George Sand i Narcyza Żmichowska. Poetka w latach sześćdziesiątych korespondowała również z Pauliną Wilkońską (zob. rkps BCz, sygn. 11911).

Zob. rkps BCz, sygn. 11911. 
nych do druku, udało się Liberze wydać w 1862 roku tylko jedną z nich: O kobietach (Rozprawa przez Kobietę) ${ }^{13}$. Spod jej pióra wyszło też kilka artykułów dotyczących kwestii narodowości w muzyce oraz wypowiedzi o charakterze krytycznoliterackim.

Niniejszy wybór pochodzi z niepublikowanych dotąd pism Libery, zgromadzonych w Bibliotece Książąt Czartoryskich w Krakowie. Prezentuje ważną część dorobku piśmienniczego jednej z najaktywniejszych i najbardziej znanych poetek dziewiętnastowiecznego Krakowa. Rękopisy zachowały się w dość dobrym stanie, są to przede wszystkim obustronnie zapisane karty w poszytach typu notesowego, czasem mało czytelne (pogarszajacy się wzrok pisarki). Podstawę wyboru stanowią następujące utwory Anny Libery:

- Sa kobiety i nie ma kobiet (rkps BCz: Osobiste, korespondencja i publicystyka, sygn. 11911, k. 3-5, dat. 1842)

- Kobieta i jej przeznaczenie. Wstęp do rozprawy (rkps jw., k. 1-3, dat. 1842)

- Uwagi nad dziełami J.I. Kraszewskiego pod napisem „Pamiętniki nieznajomego" (jw., k. 1-5, powst. ok. 1847)

- Porównanie klasycyzmu z romantyzmem i jakie zaszły walki przy wprowadzeniu tego ż (jw., k. 1, powst. ok. 1872)

- O muzyce (jw., k. 1-3, dat. 1872)

- Krakowiaki (rkps BCz: Utwory literackie wierszem, sygn. 11915, z. 24, k. 11, powst. ok. 1848)

- Jadwiga. Obraz dramatyczny w trzech aktach (rkps BCz: Utwory sceniczne, sygn. $11913, \mathrm{k} .3-11$, dat. 1843)

Modernizacja pisowni wymienionych utworów została dokonana na podstawie ogólnie przyjętych zasad sformułowanych przez Irenę Klemensiewicz-Bajerową ${ }^{14}$. Pozostawiono formy gramatyczne wyrazów, charakterystyczne dla polszczyzny XIX wieku - między innymi wyrażenia typu „kilką”, „najmonotonniejszą”. Wprowadzono niezbędne emendacje, bez których pewne partie tekstów Libery mogłyby być mało czytelne. Tytuły pochodzą od poetki.

13 Zob. [A. Libera], O kobietach (Rozprawa przez Kobiete), „Niewiasta” 1862, nr 28, 31, $36-37$.

14 Zob. I. Klemensiewicz-Bajerowa, Modernizacja pisowni w tekstach z pierwszej połowy XIX wieku, „Pamiętnik Literacki” 1955, z. 3, s. 144-158. 


\section{WYBÓR PISM NIEWYDANYCH}

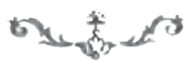

\section{SĄ KOBIETY I NIE MA KOBIET (FRAGMENT)}

Od początku dziejów ludzkich widzimy tajemniczą zagadkę, do dziś jeszcze nie rozwiązaną, że istnieje połowa rodzaju ludzkiego w fakcie, tj. żyje spełniając funkcje życia w całej rozciągłości organicznej, wychowuje płód swój, pracuje w zakresie stanowiska, w jakim los ją umieścił, uczy się znaglona potrzebą lub zmuszona przez rodziców, opiekunów i stada, nabywa talentów z różnych przyczyn na nią wpływ wywierających, dochodzi nieraz artyzmu w sztukach pięknych, nawet porwana prądem okoliczności staje się bohaterką, podczas gdy Krwawa Bellona ściele trupem tysiące mężczyzn, ślepo posłusznych zwierzęcemu jej barbarzyństwu. Są kobiety, gdyż nimi jak mężczyznami zapełniona jest kula ziemska. Oprócz miast i wsi wynikają skądś niepostrzeżenie po stepach i pustyniach, po morzach i wszędzie, gdzie tylko mężczyzna przezwany człowiekiem udaje się lub zapędzi. Przyjemnie też, lubo i wesoło [jest] ${ }^{1} \mathrm{z}$ jej istotą ciekawą, wrażliwą, przenikliwą, pogodną, cierpliwą i na wszystko wytrwałą. Gdzie stąpi, wyrastają spod jej stóp kwiaty życia, uśmiechu i nadziei. Oczami kamienne wole pociąga za sobą i kruszy, słowami rozpieszcza, jak i roznamiętnia wszelką moralną gnuśność lub obojętność. Pięknym obliczem zsyła natchnienie, budząc uśpione dusze; słowem, pod względem moralnym jak fizycznym, kobieta istnieje jako subtelność dodatnia, uwiadamiana dla człowieka mężczyzny, przez którą stał się tym, czym dziś jest i w następnej będzie przyszłości. Symbol Pisma Święte-

1 Uzupełnienia w nawiasach kwadratowych pochodzą od autorki niniejszego opracowania. 
go najjaśniej maluje nam tę prawdę. Pierwszy mężczyzna w raju w stanie swej niewinności uczuł nad sobą przewagę kobiety, powodując się jej słowy więcej niż rozkazem samego Boga i w następstwie nie lękając się zasłużonej za zuchwalstwo kary. Ta filozoficzna głębia przyrody ludzkiej w Adamie i Ewie staje w zrozumieniu najdokładniejszym, czym są kobieta i mężczyzna względem siebie i jak nawzajem siebie oddziaływają.

Uległ pierwszy mężczyzna subtelności własnej odnalezionej w kobiecie, pochwycił ją i stał się samodzielnym. Gdy idea moralna nie była jeszcze udoskonalona dla istot mających ją pojmować, natchnienie przeczuwało wyższą potęgę duchową, której fizyczność ludzka ulegać miała niezbędnie. Tuż zaraz stanęła do walki z natchnieniem materia, córa przyrody, uwiadamiana w ludzkim ciele. Obydwa te czynniki w pierwszych chwilach wydobytego życia poszły z sobą w zapasy i zwierzęcość w niewydoskonalonym mózgu człowieka wzięła górę. Pierwszą niechybnie myślicielką przez ciekawość była kobieta; dopiero naśladowcą jej mężczyzna. Od początku więc istniała kobieta przez myśl bystrzejszą, na której zbywa to mężczyźnie, aby chciał poznać, co jest złe, a co dobre, gdyż bez tych dwóch głównych wiadomości nie mógł się ród ludzki podnieść ponad stan zwierzęcy, instynktowny.

Uczyniwszy Pismo tę wzmiankę o kobiecie pierwszej, pomija ją dalej jakby z przestrachu, aby tej nie przypuścić do równowagi z mężczyzną, a tę jej wyższą korzyść myśli zetrzeć zupełnie.

Po Ewie w dziejach człowieczeństwa, skreślonych przez Mojżesza, staje na widowni wszelkiego organizmu pierwotnych społeczeństw sam tylko jedynie mężczyzna jako prawodawca, pan wszystkiego co pod słońcem i pan słabszej od siebie fizycznie kobiety.

Już idee moralne zasiane przy stworzeniu w sercach pierwotnych ludzi poczęły się z nich wykuwać i w moralne rozwijać kwiaty. Uczuwano sprawiedliwość i niesprawiedliwość, piękno i brzydotę, zacność charakteru i jego podłość; przecież nie równoważyła się ludzkość, zostając w milionowej części zaledwie tym, czym być winna, gdy ogół jej był barbarzyński, czysto zwierzęcy i nadto okrutniejszy od najdzikszych zwierzów. Pośród tych srogości jak anioł cichy zniknęła ze świata czynów kobieta, zamknięta z dziećmi, służebnymi w czterech ścianach domowych, gorzej nierównie, zamknięta w swym mózgu przemocą praw, jakie sobie nadał mężczyzna, trzymając ją w ciągłej niewiadomości i największej ciemnocie.

Jak Dantowskie cienie czyścowe kroczyła w ludzkości przez ziemię, drżąca ze łzami w oczach, pokorna służebnica swego pana mężczyzny, wieczna jego niewolnica, gdyż oprócz hańbiącego poddaństwa prawu przemocy, żadne inne prawodawstwo nie istniało dla niej. 
Oddana bezczynnej grzeczności, [kiedy] mózg jej przestał funkcjonować, stała się więc stopniowo niedołężną na umyśle niepojmującą swego stanu, stała się idiotką. $Z$ tego niewolnictwa kobiet i ich niedołęstwa wynikło w następstwie przekonanie, iż nie mają duszy. Tym ciemnym, hańbiącym swe wieki zdaniem zachwycali się filozofowie i prawodawcy, dosięgło ono i naszych niestety czasów, któremu obecnie należy się rzucić wieczną wzgardę, choćby je głosili tak genialni myśliciele, jak Krasicki, Trentowski i Libelt, i wielu, wielu innych powtarzających pacierz za panią matką.

\section{Przypisek}

Krasicki twierdził, że kobieta staje się brzydką, traci wdzięk, jeżeli oddaje się myślącym naukom i pisaniu ${ }^{2}$. Zatem ma być wiecznie ciemną. Trentowski w Chowannie wyraził się, że uczona kobieta to uczona krowa ${ }^{3}$. Trywialność hańbiąca tak wielkiego filozofa. Libelt w dziełku Humor dowodził wyraźnie, że kobieta nie jest zdolna pojąć nawet chronologii, a zbywa jej na logice ${ }^{4}$. Dopiero Krasiński, jako filozof i poeta, przemówił z serca i rozumu za wyzwoleniem kobiet, nie bez racji, gdy one same swymi dziełami przemówiły wprzód za sobą 5 .

Ubiegłe lat tysiące pomimo swego ślimaczego postępu nie odnalazły kobiety, aby jej dać miejsce w czynach i dziejach. Pyszny ze swego panowania mężczyzna nie chciał na krok ustąpić ze swego piedestału, łudząc ją fraszkami lub przestraszając okrucieństwem. Jeżeli z ukrycia wychodziły na jaw jej zdolności w wszelkim rodzaju, te pominięto milczeniem lub okryto śmiesznością tak dominującą, że nie śmiały występować, aby nie być wykluczone z towarzyskiego życia. Czuł to dobrze ogół kobiet prawie we wszystkich stanach, bo smuciły się matki, łzy roniąc przy wydawaniu na świat córek. Sami ojcowie srogo obchodzili się ze swymi żonami, które im nie ro-

2 Libera może mieć na myśli fragmenty Pana Podstolego (np. cz. 1, ks. 2, rozdz. 7), w których mowa o edukacji kobiet. Nie znajdujemy tam jednak tak ostrych sformułowań.

3 Zob. B. Trentowski, Chowanna, czyli system pedagogiki narodowej jako umiejętności wychowania, nauki i oświaty, słowem wykształcenia naszej młodzieży, Poznań 1846 t. 2, s. 502-503.

4 Zob. K. Libelt, Humor i prawda w kilku obrazach, Petersburg 1852, s. 6-7.

5 Libera może mieć na myśli fragmenty z Przedświtu, np.: „Nie ma także podrzędnicy! / Bo niewieście w końcu serce / Po lat długich poniewierce / Błysło z pączka tajemnicy” (Z. Krasiński, Dzieła literackie, oprac. P. Hertz, t. 1, Warszawa 1973, s. 186). Przypomnijmy również (bez względu na ironiczny kontekst) słowa Filozofa z II części Nie-Boskiej komedii: „Powtarzam, iż to jest nieodbitą, samowolną wiarą we mnie, że czas nadchodzi wyzwolenia kobiet i Murzynów" (tamże, s. 320). 
dziły synów. Wiedzą o tym wszyscy, bośmy zastali jeszcze tę przerażającą ciemnotę, przez to nic dziwnego, że kobiety ogłupione i ujarzmione, ulec jej musiały, jak przed niedawnym czasem milionowe masy ludzi nieuznawane były za ludzi.

\section{뿔 \\ KOBIETA I JEJ PRZEZNACZENIE. \\ WSTĘP DO ROZPRAWY (FRAGMENT)}

Zaczynając tak ważny przedmiot, a tym samym trudny w wyłożeniu należnym, osobliwie w wieku przesilającym się w najdrobniejszych szczegółów wyrażeniu, w którym myśl ulotna, spostrzeżenie bez żadnych zasad, słowem rozbiór przedmiotu nic nieznaczącego, wywołuje całe bogactwo języka, mnóstwo wyrazów posiłkowych obcej nam mowy i wszystką nieomal wytęża siłę myśli na to, co nigdy nie będzie użytecznym czytającemu i piszącemu. Jeżeli drobnostki podobne wymagają tyle mozołu i nauki, ażeby niemi brzęczeć i zyskać stąd sławę gruntowną, czyli raczej wiarę czytelników, jakiż wykład przyswoić wypada rzeczom wielkim, wzniosłym i użytecznym? Nie tak podobno teraz łatwo wystąpić z jaką gałęzią piśmiennictwa przed publicznością nawykłą rozwikływać zawiły styl wyrazami filozoficznymi, porodzonymi niedawnymi czasy i z szybkością rozpleniającymi się, o których można wyrzec, iż „padło nasienie na ziemię dobrą"; styl zaciemniony myślami bez myśli, pomagający znużeniu czytającego, pochodzącemu z nowego makaronizmu greczyzny, łaciny, francuszczyzny itp. Któż ja, kobieta, odważając się zaczerpnąć kropelkę zdania w źródle umysłowości, mam zaszczyt uwiadomić wielce łaskawych czytelników, iż pozwalając na teraźniejszy styl takowity, nim wyrażać się nie umiem i nie chcę, a zatem nie będę. Nie masz w tym nic dziwnego. Popchnięta duchem wieku, w którym kobiety wywieszają złoty sztandar wolności swojego ja, czyli natchnione uczuciem swej mocy, objawiają go światu na przekór wiekowym klątwom ich poniżenia, pospieszam i ja za nimi, nie po laur zwycięski, lecz po cierniową koronę, z jaką czeka egoizm (samolubność) płci męskiej, [aby] wieńczyć skronie pierwszych apostołek niewieściej umności. Uważam za powinność oświadczyć takowym czytelnikom lubo to ze złej strony uprzedzić mnie może, iż żadni wielcy mistrze lub mistrzynie nie zajmowały się moim wychowaniem, oprócz pobożnej i cnotliwej matki, ojca szanownego (na którego pochwałe kilka tylko wierszy byłoby ubliżeniem czci pośmiertnej) i kilka zakonnic, uczących mnie robót niewieścich i pobożności. Czyniąc to wyznanie, przyznaję jednak, iż [choć] nieboszczyki ciałem, różne geniusze nieśmiertelne od samego dzieciństwa zanosili szepty do mego niewieściego umysłu. Ja ko- 
chałam serdecznie ich towarzystwo, najprzód bajeczki, piosneczki, później sentymentalne romanse, komedie, tragedie itp. A zaś teraz szepczą mi, słabej niewieście jakąś wyższą uczoność i zapraszają do wysokiego rozmyślania nad ziemską wiedzą. Pokusy, prawdziwe pokusy, na których wypędzenie znaku krzyża świętego jeszcze nie próbowałam, gdyż zdaje mi się, że je najmniejsza wiara moja sankcjonuje. Lecz z jakimże upodobaniem poważam się przyjmować do serca przedmioty przechodzące wysoko moje słabe pojęcie? Jak odważając się, ośmielam podnieść przekleństwem przygnębiony umysł ku rzeczom przechodzącym umność milionów mężczyzn? Niewiasta wychowana w zaciszu domu i klasztorze, a co gorsza w rodzinnym swym kraju zaledwie znająca jeszcze dziesiątą jego część? Wyznam szczerze, iż tylko w oczekiwanym pobłażaniu obudzam swój zapał, a cokolwiek nakreślę, zawsze z prawdziwym zostanie hołdem dla męskiej mądrości, ma się rozumieć wyraźnie mądrości; bo lubo jestem kobietą, jednak nie wszystkim mężczyznom szafuję na ślepo tym boskim znamieniem. Nie wiadomo mi dotąd, czyli który z grona prawdziwych mędrców zajął się szczerze wyłożyć teoretycznie znaczenie moralne połowicy swojej. Tej ubóstwianej niebianki w romansach, tej niedołężnej pośredniczki między małpą a człowiekiem mężczyzną, w filozofii, bo takie tylko dotąd kobieta zajmuje przejścia, takie stanowiska obok swego bożka, które ja odrzucam, nie wierząc w oboje żadną wiarą $[\ldots]$.

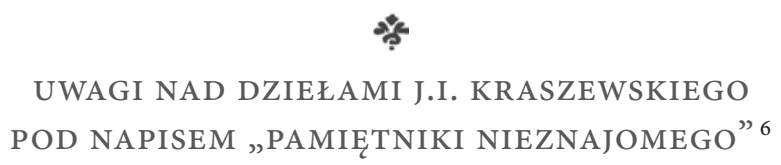

Odważając się wystąpić przeciw autorowi, który olbrzymiością utworów, nauką, talentem powieściopisarskim na znakomitym stopniu sławy dzisiaj zostaje, znam aż nadto, iż wielu jego wielbicieli na siebie oburzę, zwłaszcza jako kobieta niemająca nic wspólnego ani z żywotem autora, ani z nauką jego, na koniec z talentem. Wyznaję przecież, iż zabierając się do tej nierównej walki, nie czuję w sobie bynajmniej najmniejszego naruszenia bojaźni, bo dzielę

6 W rękopisie zachowała się także druga wersja tej rozprawy o nieco zmienionym tytule i treści - Mnie się tak zdaje, czyli: Uwagi kobiety nad dziełami J. Ig. Kraszewskiego w ogólności, opatrzona datą 1847. Libera wspomina tu kobiety - pisarki - Elżbietę Drużbacką i Klementynę Tańską-Hoffmanową. Kraszewski, jak wiadomo, cieszył się w Krakowie nie tylko sympatią czytelników - estymą otaczało go przede wszystkim środowisko miejscowych literatów i uczonych, które z kolei nie ceniło pracy twórczej Libery, co może poniekąd wyjaśniać niechętny pisarzowi ton artykułu Krakowianki. Powieść Kraszewskiego Pamiętniki nieznajomego (w autografie Libery: Pamiętnik...) ukazała się w Warszawie w 1846 roku. 
czyste przekonanie prawdy, osłaniające mnie silną swą potęgą, podwajające moją odwagę oraz wzmacniające moje podejrzenia o jakiejbądźkolwiek interesowności prócz wynurzeń serca i rozumu, co się sercu i rozumowi nie podoba. Nie jest mi wiadomo dotąd (jako niemającej czasu i sposobności odczytywać pisma w rodzaju krytyki i recenzji), o ile dzieła Kraszewskiego są cenione przed sądem zdrowej, bezinteresownej krytyki i czy wziętość swoją obecną na czas potomny zabezpieczają. To tylko znam, iż obecnie są czytane przez młodzież płci męskiej (ujmując płci mojej, bo ta do dziś dnia mało jeszcze czyta i rozumuje w krajowej literaturze) mającej u nas mało pojęcia [... ${ }^{7}$ we wszystkich gałęziach sztuk pięknych, co tym jest gorzej, że na utworach Kraszewskiego się nie znają, bo te mają za cel obrazowanie już nie wzniosłości ani nie charakterów, ale wszelkich ułomności indywidualnych, towarzyskich i społecznych. Gdyby to w ogromie kilkudziesięciu dzieł podobało się autorowi przedstawić zło celem jego obrzydzenia, nie w sposobie obojętnym, jakby to istnieć powinno koniecznie, nazwalibyśmy ten fakt przysługą lekarską, która chociaż pozornie przykra choremu, przecież go uzdrawia. Ale to jakby z rozmysłu, obraz po obrazie czarniejszy, szkic po szkicu obrzydliwszy tak dalece, iż już nasza literatura beletrystyczna, niecechująca poczciwej narodowości, krok w krok pod piórem Ignacego Kraszewskiego postępuje za szarlatańską literaturą francuską i znowu jak za czasów śp. stanisławowskich, krojem pożyczanym, naśladowniczym swoje piękne odziewa ramiona. Wprawdzie bezcenna w nas moda przyswajania sobie obcych śmieszności, w chęci odróżniania się od drugich - przyswajania przywar, błędów, a nawet i występków - zatem urojeń, egzaltowania, namiętności - wywołała obyczaje nieswojskie, które jako chorobę cudzoziemską, zagraniczną, środkami cudzoziemskiego klimatu leczyć należy, w obrazowaniu symptomatów, kryzysie, śmierci samej. To wyrachowanie na pozór stałoby się wielce zbawiennym, gdyby autor - lekarz moralny, chwytając się ostatecznych środków, zechciał nam pokazać również środki wyzdrowienia. Lecz [ten] postępując kontra wszystkim tym, co utwierdzali w dobru osobistym lub bądź dla osobistego, bądź ogólnego dobra, szkicuje występki i błędy bez sprawiedliwej kary, zostawiając poświęcenie i cnotę w rozpaczy bez najmniejszej pociechy ziemskiej a nawet religijnej, dowodząc jawnie władzy ślepego fatum i prawa mocniejszego w podłym intrygowaniu o znalezienie szczęścia materialnego. Kto z dzieł podobnych, improwizujących po większej części prawdy moralne, może poczuć w sobie wyższość, zapragnąć dążności do niej, gdy rzadka wia-

7 W nawiasach kwadratowych oznaczono te fragmenty tekstu, których nie udało się odczytać z rękopisów. 
ra w nią nie ma swej silnej strony, mimowolnie poruszającej wrodzoną człowieka ku dobremu sympatię? Zło, nawet zło zwyczajne, pospolite, bezwstydne, triumfujące nad dobrem, w końcu śmierć wspólna wszystkim, oto cała tendencja i naddatek wszystkich obyczajowych i nieobyczajowych powieści Kraszewskiego, a co gorsza, iż czytając jedną, te same obrazy, charaktery, myśli i dążenia u wszystkich napotkasz, co prawdziwie aż do znudzenia monotonia. W chęci znalezienia przecież czegoś nowego, z myślą, iż wszystko postępuje i doskonali się, czemużby i nie [mieliby doskonalić się] autorowie? Wzięłam do ręki Pamiętniki nieznajomego. Na pierwszej zaraz stronie poznałam mowę autora dobrze mi znanego pod względem ironii ze wszystkiego tego, co człowiek najświętszego ma w tym życiu. Juliusz na samym wstępie objawia się z tym bluźnierczym szyderstwem, które chociaż autor w końcu uprawnia, przecież już nie wyciąga jadu zwątpienia o szczęściu, zaprawiającego całe człowieka życie. Nie zastanowił się autor, jak uwzględnić złamaną szczęśliwość ludzką w osobie młodzieńca, pieszczocha [...] i macierzyńskiego jedynaka, który oprócz zawodu w miłości wspólnego prawie wszystkim marzącym ideały ziemskie, niedojściem do celu lub po dojściu odczarowany, który równie silniejszej nie doznawszy w życiu przygody, ma się za coś wyższego, iż jedną kochankę ubóstwianą poświęcił [dla] drugiej, drugą odstąpił na perswazje matki i Wrzoska, i sam odważnie jak doktor był przy jej gasnących chwilach życia. Z trzecią ożenił się bez miłości, tylko ze spekulacji pieniężnej, oraz że matka wmówiła w niego, iż potrzebuje żony, która by za niego myślała o gospodarstwie i o nim itp. Z myśli, którymi Juliusz strzela ogniście, a które często są tylko absurdami, osobna byłaby książka, co zaprawdę lepsze byłoby, jak te wszystkie pospolite charaktery, rzucone jak w panoramę bez żadnego z sobą związku. Jeden obraz Wrzoska błyszczy świetnie wpośród całego dzieła jak nić złota między pośniedziałym szychem ${ }^{8}$. Nie będę wyliczać innych charakterów męskich od niechcenia niby kreślonych, bo na cóż o tym szeroko rozprawiać, co samo tylko obszernie się wytłumaczyło w swojej nicości. Co do kobiet idealizujących każde dzieło dobrego autora, z tymi Kraszewski postępuje w każdym ze swych utworów na jeden despotyczny, azjatycki sposób. Usiłuje on jak geniusz mieć je wszystkie na jeden model, zwykle naczyń próżnych i tylko do wygody mężczyzny służących. Życzy on widzieć je z sercami, bez głów, z uczuciami wyższości bez wykształcenia, z religią bez jej gruntowniejszego poznania, słowem sięga on wieków Mahometa, w których ciemnota trzymająca dumnie berło nad światłem za-

8 Szych - nitka owinięta drucikiem, używana do haftów i wyrobów pasmanteryjnych; daw. „pozorna świetność”. 
dawała niby uczone kwestie, czy płeć druga jarzmiona fizycznie i moralnie posiada duszę? Kraszewski albo nie zna istotnie kobiet ze strony ich najszczytniejszej, albo poznając, lekceważy, co jest zgorszeniem współczesnym, lub zawiedziony przez nie w swych nadziejach, mści się okrutnym sposobem za własną osobistość. Nie pomaga, że tym środkiem zadaje krwawe rany religii, społeczeństwom i moralności, na które to trzy głośne stanowiska każda bez wyjątku wpływa kobieta jako druga połowa rodu ludzkiego, mająca bliższe w tych instytucjach stosunki od mężczyzny, bo będąc matką pokoleń nowych, całą im siebie poświęca. Nie sławmy Kraszewskiego, że maluje typy kobiet błyszczących talentami, napuszonych próżnością, a oddających się jedynie bezczynności, zabawom i intrygom miłosnym. To są ładne nawet piękne niekiedy potwory nieharmonizujące ze swym rodem, raczej politowania niż ironii, nauki niż wstrętu godne. Znieważają sobą cały rodzaj kobiety, szczególnie rodzaj postępowy, do którego dzisiaj cała nasza ludzkość olbrzymim krokiem się posuwa. Miałybyśmy my tylko kobiety wiecznie i wiecznie od przybytków boskiego światła być odpychane? Z dzieł, które pamiętne, wyliczę tu ofiary szyderstwa: i tak w [powieści] Świat i poeta Julia lubiąca literaturę, dająca o niej swe zdanie, znudziała zarozumiałego Gustawa i zaraz miała usposobienie do obcych miłostek, choć platonicznych. W Czterech weselach kobietę więcej światłą od drugich zrobił po prostu nierządnicą. W Czarnoksięskiej latarni tam już bez liku odbić literatek wykształconych na skalaną stronę. W Twardowskim, a nawet w Stańczyku, toż samo. Całe życie bieda - i tam kobieta sponiewierana moralnie.

[...] W Pamiętnikach Nieznajomego Iza i Emma całkiem nic niewarte, bo wykształcone, utalentowane. Niechże więc autor sam w sobie się zastanowi, że w szczerej ciemnocie niewiadomości szuka ideałów na wzór ślepego, co nie mogąc rozkoszować w widoku światła, maca kształty gładkie, sprzyjające innemu zmysłowi i w tych z potrzeby się kocha. Żal mnie ogarnia, serce mi się ściska - bojując przeciw takiej niesprawiedliwości. Mogłabym z dziesięcioro za takie szyderstwa zapłacić; byłabym w stanie przytoczyć dość silnych faktów na obronę postępu oświaty w kobietach, lecz tak nieznośny wstręt czuję do tłumaczenia prawdy, tak ją szanuję wysoko, iż próżną gadatliwością obrazić ją się lękam. Kończę przysłowiem „Mądrej głowie dość dwie słowie” oraz radzę Kraszewskiemu czytać dzieło o ateistyczności małżeństwa, przez Niemca pisane ${ }^{9}$, a w czym z umysłu nie rozciąga się zupełnie, niech pojmie w swojej żonie i córkach.

Libera odwołuje się prawdopodobnie do dzieła Immanuela Kanta Rozprawa filozo- 
PORÓWNANIE KLASYCYZMU Z ROMANTYZMEM I JAKIE ZASZŁY WALKI PRZY WPROWADZENIU TEGOŻ

Zbyt długo pewne formy, których nie wolno było przekroczyć poecie, oraz mieszanie mitologii greckiej do porównań poetycznych więziły polot wyobraźni co do zewnętrznego wkładu pieśni i poematów. Ślepe naśladownictwo Wergiliusza, Horacego, Anakreonta i całej plejady poetów greckich i rzymskich, wlokło się niewolniczo przez ostatnie stulecie, jakby zaprzężonych przy ich tryumfalnych wozach. Jeżeli kto nie czuł muz starożytnych i nie dedykował im swej pracy, poczytany był za nieuka. A cóż dopiero, jeżeli zamiast porównań prostych z przyrody, nie wyliczał co wiersz Marsa Bellony - Minerwy - Wenus - Kupida i całego orszaku bóstw, stawał się nie poetą, lecz jej niby profanem, chociażby czuł w sobie inne poezji formy, inne do malowania prawdy. Zachodził jeszcze i ta śmieszność, że poeci chrześcijańscy, często nawet w pobieżnych pieśniach odzywali się do powszechnie używanych tych bóstw pogańskich, a wszystkie europejskie wykształceńsze narody jedną i tę samą przyjęły zasadę w poezji, zowiąc ją klasyczną. Pomimo szacownych pochwał klasycyzmu, był on ckliwym, smutnym jak stara, zużyta suknia, przetarta i spłowiała. W samej rzeczy, ten oklepany sposób pisania wierszy sprawił, że śmiano się z poetów, a ich płodami gardzono. Zdarzali się nieraz prawdziwi geniusze poezji, depcący te niewolnicze formy klasycyzmu, lecz tych mała była liczba. Takimi byli Dante Aligheri, Petrarka, Szekspir. Dopiero w osiemnastym stuleciu Goethe i Schiller u Niemców pierwsi rozpoczęli wiek romantyzmu, złamawszy formę i ducha poezji klasycznej.

\section{O MUZYCE}

Wymowny wyraz „muzyka” już czaruje naszą wyobraźnię wraz z uznaniem pragnącym usłyszeć melodię z harmonijnych złożoną tonów, wzruszającą nas w miarę twórczości kompozytora. Najciemniejsze plemiona ludzkie nieznające rozkoszy poezji, lubują z zapałem w dźwiękach muzyki, choćby ta była najmonotonniejszą, byle jej odgłos dotykał ich uszu, porażając zastygłe chwilowo uczucie ducha. Wrodzona harmonia muzyki tętni w nas ciągle; stąd ten poryw, uniesienie, zapał lub tkliwa rzewność obejmuje serce za posłyszeniem tego, co w nas tkwi uśpione, a budzi się na pierwszy dźwięk cza-

ficzna o religii i moralności (przekł. pol. Mrongowiusz, Gdańsk 1854). Filozof przedstawił w nim małżeństwo jako umowę dwóch wolnych i równych sobie osób. 
rownie śpiewanych lub hucznie brzmiących tonów. Każda narodowość stosownie do swego umysłowego rozwoju, klimatu, doznanych klęsk oraz innych względów i przyczyn, ma swoją odrębną pieśń uczuć, stanowiącą narodową muzykę, którą pojmuje, kocha, nie przywłaszczając sobie innej jako nierodzimej, nieswojskiej. Pienia tej pieśni rozstrzelają się znów na wielorakie utwory fantazji, znać jednakże w każdym, że z jednego pochodzą szczepu. Któż nasze krakowiaki, mazurki, obertase może nazwać czeskimi, węgierskimi lub ruskimi, a poważne polonezy francuskimi lub angielskimi? Która narodowość posiada tak rzewne, bólem duszy i jękiem serca odznaczające się dumki jak ruska, czardasze madziarskie skoczne, razem tak melancholijne, zdając się niby rozkochane w tęsknocie beznadziejnej? Plemiona słowiańskie mają całkiem odrębną swą muzykę od innych plemion Europy, germańskiego i romańskiego, jak równie kotyliony, anglezy, sztajery, walce inną mają żywotność, fantazję, duszę. Wielcy kompozytorzy niemieccy, włoscy, francuscy swoim utworom nadali obywatelstwo wszystkich krajów. Opery ich, tańce, uwertury przyniosły sobie wszystkie części kuli ziemskiej i stąd zdawałoby się, że muzyka równie jak poezja przez geniuszów do najwyższej potęgi rozwinięte, zagładzone zostaną w cechach swojej swojskości. Pomimo wysokiego ich wydoskonalenia, milionowe ludy strzec zawsze będą swej żywotności i prostoty tych obydwóch i jak wyraził [się] najgenialniejszy poeta, w arce swojej zachowa ich świeżość, z której przyszłość czerpać będzie nowe zawsze natchnienie. Piękność, lube wrażenie muzyki, kto powiedzieć, kto opisać zdoła? Jej wpływ cudowny znany wszystkim, kto czuć wyżej i pojmować umie, a jak nieocenionymi są mistrzowie jej niebiańskich tonów. Oprócz zabaw, obrzędów weselnych i pogrzebowych - teatrów i parad wojskowych, muzyką ściągnął do siebie święto-poważny Kościół katolicki i szczytnie ją podniósł jak malarstwo religijne, w której panują dotąd nieśmiertelni: Rossini, Bach, Haydn i Mozart. Życie nasze ubiega wśród jej rozkosznej melodii, począwszy od kolebki, gdzie ponad nami upływają piosenki matki i to nie te miłe, choć niezrozumiałe jeszcze tony, dagerotypowo odciskają się na uczuciach serca, że dwuletnie dzieci, poczynamy już bawić się śpiewem i w piosnki wsłuchiwać. Czy mamy wyższą swoją narodową muzykę? Wypowiadam: nie. Nieszczęśliwe naśladownictwo jeszcze jej się rozwinąć nie pozwoliło. Przedstawicielami jej zaledwie są Chopin i Moniuszko, tejże dwa arcymistrze z pochodniami swych utworów stoją w bramie przyszłości naszej narodowej kompozycji, poprzedzających tych, którzy zrozumiawszy ducha narodu, przyciągają go ku sobie, że ten ich ukocha i swoimi nazwie. 


\section{KRAKOWIAKI}

Polak jestem Polak, z krwi pochodzę polskiej,

Nic mi nie brakuje, chyba łaski boskiej.

Chyba łaski boskiej, chleba do siwizny

I coś najdroższego, to lubej ojczyzny.

Polaku, Polaku, nie kochaj się w fraku,

Kochaj się w żupanie, jak dawniej, mospanie.

Gdyby w każdym sercu polska sprawa żyła,

Dawno by się Polska wolności dobiła.

Panowie hrabiowie, cóżeście zyskali,

Żeście matkę polską zdradziecko sprzedali.

Jakoście sprzedali, tak ją odkupujcie,

Krwi, życia, majątku dla niej nie żałujcie.

Janek w karczmie śpiewa, nogą przytupywa,

Czapeczką potrząsa - w górę kręci wąsa.

Chociaż ci ja nie pan, nie miejszczak, ni kupiec,

Nikt mi nie zarzuci, bym był jaki głupiec.

Chodź sobie, mospanie, w niebieskim żupanie,

W butach z obcasami w płaszczu z potrzebami.

Wiem, czym jestem, jakim z pradziadów Polakiem,

Nadwiślańskie dziecko, gnębione zdradziecko.

JADWIGA. OBRAZ DRAMATYCZNY W TRZECH AKTACH ${ }^{10}$

Osoby

Jadwiga - Królowa polska

Katarzyna z Melsztyna - dziewica przy boku Jadwigi

Dramat napisany w trzech wersjach; w rękopisie dostępny także jako: Jadwiga. Królowa Polski. Moment historyczny w aktach napisany oryginalnie z 1865; Poświęcenie Jadwigi Królowej. Moment dramatyczny w trzech aktach oryginalnie napisany 1866. Być może trzecia wersja dramatu Anny Libery powstała z inspiracji dziełem Józefa Szujskiego i poglądami tego pisarza na temat roli dramatu, wyłożonymi w przedmowach do jego dzieł, jak i w artykułach zamieszczanych w „Czasie”. Libera do poglądów Szujskiego odnosi się w artykule: Myśli moje o kwestii żydowskiej traktowanej na Sejmie Galicyjskim w r. 1866. Odpowiedź na list trzeci p. Józefa Szujskiego, zamieszczony w „Czasie” 11 II (rkps BCz, sygn. 11914, t. 1). Temat królowej Jadwigi pojawia się także w listach Libery do Adama Bełcikowskiego. Także sam Bełcikowski posyłał poetce fragmenty swego niewydanego dramatu Królowa Jadwiga - por. list Adama Bełcikowskiego z 1860 roku, Korespondencja Anny Libery, rkps BCz, sygn. 11911. 
Wilhelm - książę rakuski ${ }^{11}$

Goraj Dymitr - kanclerz państwa

Zbigniew Oleśnicki

Jaśko z Tęczyna ${ }^{12}$

Pustelnik z Puszczy Niepołomickiej

Giermki - dworzanie - lud

AkT I

\section{SCENA I}

Komnata Jadwigi na Zamku Królewskim w Krakowie, oświetlona lampą wisząca u powały. Jadwiga i Katarzyna

Katarzyna

Gdy dotąd cały zamek w słodkim śnie spoczywa

Cóż ciebie, droga pani, z pieszczot snu wyrywa?

Jeszcze w cieniach pomroku szczyty miasta toną

Gwiazdy niezćmione zorżą brylantami płoną.

Oddech życia całunem noc ciemna przygniata,

Ty sama, jak królowa zamierzchłego świata.

Błądzisz po falach jego w postaci anioła,

Z blaskiem rannej jutrzenki u jasnego czoła!

Szmer z twojej komnaty dobiegł mego łoża

Nie bez lęku - gdy patrząc jako jeszcze zorza

Na kryształowych szybach nie odbiła lica,

Ledwo ucho świstania drabantów ${ }^{13}$ pochwyca,

Strzegących bram zamkowych - lub zza Wisły brzega

Z sioł czujnych zwierzów odgłos za wiatrem dobiega.

\section{Jadwiga}

Dzięki ci, Katarzyno, za tkliwą obawę!

Czuwanie to maluje moich trosk postawę:

Zrosłych z berła ciężaru w mdłej dziewicy dłoni,

I zamiast mirtu z złotej korony na skroni

Za blaskiem chwały tronu, ileż zgryzot płynie!

Monarcha życiem wszystkich jest w każdej godzinie,

Będąc sercem narodu - pulsem jego ciała,

Skąd na jego organizm spływa szczęście - chwała.

Nie dziw więc, gdy to ciało ujmie sen swą mocą,

Sercu bije - puls krąży - tak dniem, jak i nocą.

11 Wilhelm Habsburg, książę rakuski, w dzieciństwie zaręczony z Jadwigą Andegaweńską. Zaręczyny zerwała polska szlachta; dążąc do zacieśnienia związku Polski i Litwy, na męża przyszłej królowej wybrano, jak wiemy, Władysława Jagiełłę.

12 Jaśko z Tęczyna - kasztelan wojnicki, znany ze swego oddania dla królowej Jadwigi.

13 Drabant - żołnierz straży przybocznej króla. 


\section{Katarzyna}

Jeżeli poddance wolno wyrzec prawdy słowa: Dzisiaj nie troski tronu podziela królowa;

Odtąd jak z Węgier w Polski przybyłaś krainę, Naród w pokoju szczerą przedstawią rodzinę. Niepokojące duchy o zwierzchnictwa władze, Wraz ulęgły twym wdziękom i rodu powadze, Ujrzawszy w twej osobie chociaż po kądzieli,

Drogą krew Piastów prawych kraju dzierżycieli.

Obecną chwilę możesz mieścić w szczerszych rzędzie!

W królu dłoń męska ciężar berła dzierżyć będzie;

A więcej, co odnoszę do serca kobiety,

Czułość małżonka, pełna nadobnej zalety,

I cóż z twym czuciem węzeł słodyczy - wesela,

Do wielkości los przyda miłość - przyjaciela!

\section{Jadwiga}

Miłość!... jeszcze w jej moce wierzyć mi wypada, Dopóki naród moim sercem nie zawłada. I powinność nie każe utłumić płomieni; Z łona snu mnie unosi - pogrążą w dumania!

Lecz póki urok wspomnień skrzydły nie osłania, Póki obraz lubego zachwycać mnie zdoła, Koronę oddam śmiało - ale wianka z czoła Nie poświęcę innemu, by w pół świata darze, Choćby u stóp mych błagali cesarze.

\section{Katarzyna}

[Porzuć] płonną obawę - czyż królowej pani Prawo przeciw jej woli narzucą poddani?

Da Bóg w rychle doczekać, że Wilhelma skronie, Obok pięknej Jadwigi zabłyszczą w koronie; O czym Jaśko z Tęczyna najlepiej ci powie, Wchodząc w układy z radą najwyższą i pany, Zdaje się, że otrzyma skutek pożądany,

Zwłaszcza gdy przedmiot życzeń ku niemu się skłania.

\section{Jadwiga}

Oby prawdę głosiły twoje domniemania! Jednak serce za lubą skłonnością, gdy mówi, Przeczucie się przedrzeźnia mnie i Wilhelmowi: Jawę snując obecności, niepewną, wątpliwą; Snem przyszłość wyobraźni przywodząc trwożliwą. Właśnie dzisiejszej nocy dziwne miałam mary: Widma - jakie słowiański świat nasz mieścił stary. Znajdowałam się w jakimś nieznanym mi kraju, Wśród bożyszczów pogańskich w poświęconym gaju; 
Mnogie ludy do ofiar cieszyły się tłumnie, Z dala błyszczał znak krzyża na gmachu kolumnie

Pośmiewany szydersko i bluźnierstwy tony;

Nad nim ulatał anioł litewskiej korony ${ }^{14}$,

Unosząc w ręku pogoń i dwie łzy perłowe, Gorące jako ogień zronił na swą głowę;

$\mathrm{Z}$ wyrazem, melodią, anielskiego głosu:

„Jadwigo! Widzisz znak ten, jakiego dziś ciosu

Doznaję od niewiernych - któremu anieli

Dzwonią hymny pochwalne i tłumy czcicieli!

Ty sama czystą pieśnią i twoje pradziady,

Cała słowiańska ziemia - a te tu gromady,

Bluźnię - co my anioły, wy czcicie ziemiany?

Z hołdy jemu winne, biorą czcze bałwany".

Widzę! Odrzekłam smutnie - lecz czyż u człeka mocy

Sprowadzić światło pośród cieni nocy?

Jedno skinienie z Wszechmocnego wypryśnięte woli,

Naród ten $z$ bałwochwalczej wydźwignie niewoli,

Zamieniając błąd stary na prawdy ołtarze!

$\mathrm{Na}$ to anioł mi inne widowisko ukaże:

Całą lechicką ziemię za dni Mieczysława,

Pośród której Dąbrówka z krzyżem w dłoni stawa,

A za nią naród wszystek - rzucając w topiele,

Brzydkie bożyszcz posągi i nucący wiele

Hymn Bogu prawdziwemu.

I znów na to rzecze:

„Bóstwo włada natchnieniem! lecz czyny człowiecze

Wykonywają Bóstwa tajemne zamiary!

Raz przyszło słowo z nieba uczyć ludzi wiary, I słońcem pozostało w ich duszach zamknięte;

Lecz promienie mają być światu rozwinięte,

I duchów wielkich i czystych!... Patrz! twa poprzednica,

Zachwycając monarchę wdziękiem swego lica,

Tym ziemskim środkiem świętą przyniosła mu wiarę!

Jadwigo! Chceszże spełnić podobną ofiarę?

Lecz zrzec się musisz tego, co serce ocenia,

Wielkich dzieł nie dokaże nikt bez poświęcenia!

I klęknęłam milcząca - a tymczasem w dali

Anioł głównią ognistą gaje bożyszcz pali.

Wilija srebrną różą wiernym chrztu udziela,

Po świątyniach zabłysły znaki Zbawiciela;

14 Motyw anioła przychodzącego we śnie i objawiającego przyszłość mógł zrodzić się w wyobraźni Libery z inspiracji popularnym w Krakowie utworem Jana Pawła Woronicza Zjawienie Emilki, dołączonym do powtórnego wydania Świątyni Sybilli (Kraków 1832). O kulturotwórczej roli biskupa Woronicza pod Wawelem - zob. E. Gracz-Chmura, dz. cyt., s. 72-74. 
Podziwiającej z łzami tak nagłą odmianę:

Ukazał anioł me imię w mgle wieków pisane.

Po tym przeniósł widzenia nad szczyty Krakowa:

Ujrzałem, jak ludu tamtego połowa,

Miotając się z ciemnością, w nią głębiej zapada.

Żadna umnica prawdy światła nie wykłada,

Westchnęłam do anioła, rwąc na sobie szatę,

Rzucając z piersi, głowy ozdoby bogate

Jakby zajęte rozpaczą czy litości siłą.

$\mathrm{W}$ tej chwili wzrok tysiące rąk popodnosiło

I stanęła mądrości świątynia ${ }^{15}$ wspaniała.

Do niej tłumnie się polska młodzież zgromadzała,

I wkrótce wychodzili z niej mędrce i męże.

Między innymi wielą mąż u świata sławny ${ }^{16}$,

Wstrzymał słońce i ziemi przywrócił bieg pradawny!

Gdy tych cudów zdziałanych dziwię się przyczynie;

Rzekł mi anioł: „Stąd równie imię twe rozsłynie,

Żeś myśli poprzedników uwieńczyła czynem!”.

W tym skronie me dziewicze otoczył wawrzynem

I uniósł pod obłoki - wysoko - wysoko,

Odtąd już ziemi moje nie sięgało oko.

Zmąciłam się z gwiazdami i w ich światła fali

Tonęłam lekko, mile, dalej, coraz dalej.

\section{Katarzyna}

Sen ten piękny, znać wieczną przyszłość ci odsłania,

Dzieła chwały płynące z twego panowania,

Zgodne z myślą narodu i jego pragnieniem;

Niebo samo rozrządza twoim przeznaczeniem!

Jadwiga

Jeżeli senne zjawiska wywołują wiarę?

Mam z siebie poświęcenia uczynić ofiarę,

Lecz tajemnica onej pozostała w niebie!

Toż ja władczyni innych, a nie wolna siebie?

Przynosząc drugim szczęście, swego zrzec się muszę,

Może stracę, co więcej kocham nad mą duszę.

Któż wie? Nie - nie przypuszczam dręczącej obawy;

Co bądź dla dobra ludu, dla narodu sławy,

Miłość królowej zdziałać nie może przeszkody,

Zamrą dawne me duchy, mówię i wiek młody,

Gdyby znalazł się człowiek, Katarzyno droga!

By mi sen ten wyłożył zgodnie z wolą Boga,

Skarbów moich królewskich zyskałby połowę.

15 W 1400 roku królowa Jadwiga odnowiła założoną w 1364 roku przez Kazimierza Wielkiego Akademię Krakowską.

16 Mikołaj Kopernik studiował w Akademii Krakowskiej w latach 1491-1495. 


\section{Katarzyna}

Chęci moje w tym pani służyć ci gotowe:

Słyszałam o wróżbicie nad Wisły brzegami,

Wśród Niepołomskiej Puszczy, pomiędzy lasami.

Starzec ten twego dobrze zapamiętał dziada,

Kaźmierza Wielkiego, a jak wieść powiada,

Niemylność przepowiedni jego usta ronią,

Któż wie, czyli królowej prawdy nie odsłonią?

\section{Jadwiga}

Już też srebrny świt ranka jasność w okna prószy, Lżej oddycham i jakoś swobodniej mi w duszy.

Postacie przodków moich wyzierają z cieni;

Patrz jako lice Kingi wdzięcznie się rumieni!

Katarzyna

Była to w czynach pięknych nadludzka istota, Miłosierna jak niebo - łagodna jak cnota!

\section{Jadwiga}

Posag jej wiecznie polską ubogacił ziemię,

Cudem sól jej przyniosła.

\section{Katarzyna}

I za to Polaków plemię świętą ją swą uznaje.

Już na mego dziada

\section{Jadwiga}

Kaźmierza Wielkiego pierwszy promień pada

Od słonecznego koła - patrz jak się uśmiecha!

Czy w martwy obraz, ducha wstępuje pociecha

Z czynów świetnie zdziałanych! męskich kształtów lica

Rozjaśnia wspaniałości zapału źrenica.

O! za przesadę, Kasiu, nie bierz mi, kochana,

Czuję popęd i przed nim uginam kolana!

\section{Uklęka}

On krew moja! Lecz sam ród ceniłabym mało, Miał duszę, wielką duszę!

\section{Wstaje}

\section{Katarzyna}

Cóż by nie przystało?

Twym wdziękom i uczuciom? Kiedyś obok niego

Wieki ubóstwią wnuczkę króla tak słynnego.

A jako zorzy światłość, gdy deszcz słoty sieje,

Pięknością i podziwem wnikniesz w Polski dzieje. 


\section{erista \\ Edyta Gracz-Chmura (Jagiellonian University) \\ e-mail: edygrach@gmail.com}

\section{Selection of Unpublished Writings by Anna Libera \\ (KRAKOWIANKA)}

\section{A B S T R A C T}

This selection of the writings of Anna Libera "The Cracovian" (18051886) - unpublished and in fact little known - presents an important part of the writings of one of the most active and most famous poets of 19 th century Krakow. Libera was also the first Cracovian emancipate fighting for women's rights - several dozen of her papers and essays have been preserved in manuscripts, calling for a change of thinking about the role of women in private and public life. She also produced a few articles on nationality in music and critique of the literary genre. Samples of Libera's poetic and dramatic works which situate her work between Romanticism and Positivism have also been presented.

\section{KEYWORDS}

Anna Libera, Cracow, emancipation of women, Polish drama,

Polish poetry 